\title{
The Impacts of Public Expenditure, Government Stability and Corruption on Per Capita Growth: An Empirical Investigation on Developing Countries
}

Selçuk Çăgrı ESENER (https://orcid.org/0000-0002-5722-9549), Department of Public Finance, Bandirma Onyedi Eylül University, Turkey; e-mail: cesener@bandirma.edu.tr

Evren IPEK (https://orcid.org/0000-0003-4855-6545), Department of Economics, Bandırma Onyedi Eylül University, Turkey; e-mail: eipek@bandirma.edu.tr

\section{Kamu Harcamaları, Hükümet İstikrarı ve Yozlaşmanın Kişi Başı Büyüme Üzerine Etkileri: Gelişmekte Olan Ülkeler Üzerine Ampirik Bir Değerlendirme}

\begin{abstract}
This study aims to evaluate the effects of public expenditure, government stability and corruption on economic growth with other control variables namely openness and population growth. The empirical analyses are utilized by using annual panel data for 33 countries which are classified as Upper and Lower Middle-Income Countries by World Bank. The sample period covers the years between 1999 and 2014. The empirical analyses are performed by both the static panel data approach and dynamic generalized method of moments (GMM) techniques. The estimation results point out statistically significant positive impacts of government stability and openness variables on per capita growth in these developing countries. Moreover, corruption, population growth and public expenditure variables are found to cause some significant decreasing effects on economic growth.
\end{abstract}

Keywords

Economic Growth, Government Stability, Corruption, Public Expenditure, Panel Data Analysis.

JEL Classification Codes : $\quad$ E60, F43, H00, H50, O47.

Öz

$\mathrm{Bu}$ çalışmada kamu harcamaları, hükümet istikrarı ve yozlaşmanın ekonomik büyüme üzerindeki etkilerinin dışa açıklık ve nüfus artışı gibi kontrol değişkenleriyle incelenmesi amaçlanmaktadır. Ampirik analizler Dünya Bankasınca üst ve alt orta gelirli olarak sınıflandırılmış 33 ülkenin 1999-2014 dönemine ilişkin yıllık panel verileri kullanılarak gerçekleştirilmiştir. Statik ve dinamik panel veri yöntemleri kullanılarak gerçekleştirilen ampirik analiz sonuçları ilgili ülkelerde kamu istikrarı ve dışa açıklık değişkenlerinin ekonomik büyüme üzerindeki istatistiksel olarak anlamlı pozitif etkilerine işaret etmektedir. Bununla birlikte, yozlaşma, nüfus artışı ve kamu harcamalarının ekonomik büyüme üzerinde istatistiksel olarak anlamlı ve negatif yönlü etkileri olduğu tespit edilmiştir.

Anahtar Sözcükler $\quad$ : $\quad$ Ekonomik Büyüme, Hükümet İstikrarı, Yozlaşma, Kamu

Harcamaları, Panel Veri Analizi. 
Esener, S.Ç. \& E. İpek (2018), "The Impacts of Public Expenditure, Government Stability and Corruption on

Per Capita Growth: An Empirical Investigation on Developing Countries”, Sosyoekonomi, Vol. 26(36), 11-32.

\section{Introduction}

Many researchers focused their attention to analyse the determinants of economic growth. In addition to those, this paper attempts to assess the explanatory attributes of public expenditure, government instability and corruption on economic growth. There is an ongoing debate on the impacts of government expenditure on economic growth. Although several empirical studies attempted to evaluate the relationship between public expenditure and economic growth by use of various econometric methodologies, no consensus has been reached. The debate arises from the question whether economic growth is the cause of government expenditure or government expenditure is the cause of economic growth. The arguments about this matter gather around two basic theoretical approaches: Wagner's Law which supports the idea that faster growth induces larger government expenditures and Keynesian Approach according to which economies grow as a consequence of a rise in government expenditure.

Government instability is another popular issue that attracts our attention along with several scholars. It is determined as an explanatory variable of the growth model since many economists point to the economic disturbances arises from government instability. Frequently changing policies due to government instability increases uncertainty and by this way dampens economic growth. Besides, it affects macroeconomic performance adversely by shortening the policymakers' sight and so diverting to suboptimal short term policies. Additionally, there is a growing literature that investigates the relationships between economic growth and corruption. Corruption can be defined as misuse of public power for private benefit. It is included into the model as a policy variable since it has the potential to affect social and economic life in many aspects.

This paper aims to provide a contribution to the growing empirical literature on the debate over the impacts of corruption and government spending on economic growth by examining the subject for a specific country group. For this purpose, we conduct a panel data analysis in order to detect the impacts of public expenditure, government instability and corruption on per capita GDP growth for 33 middle income countries. The sample period covers the years between 1999-2014. The upcoming sections of the study are organized as follows: second section of the study examines the empirical literature on the subject. In the third section, the data set, model and the methodology of static panel data approach and dynamic generalized method of moments (GMM) techniques is introduced. The fourth section interprets the empirical results from analyses, and the last section presents the conclusion of the study.

\section{Theoretical and Empirical Literature}

In the empirical literature various studies have been concerned about the determinants of economic growth for different countries or country groups. This paper focuses on the impacts of public expenditure, government stability and corruption on economic growth. Therefore, the following subsections demonstrate some examples from the empirical literature about the links in interest. 


\subsection{Public Expenditure and Economic Growth}

Wagner's Law and Keynesian Hypothesis are the two main perspectives concerning the relationship among government expenditure and economic growth. According to Wagner's view, government expenditure enlarges faster than economic growth. Besides, Keynesian view states that government expenditure stimulates economic growth (Ono, 2014: 3523).

Wagner's (1890) Law supports a causality relationship running from economic growth to government spending. Why economic growth is seen as a cause of government spending can be explained by three reasons: i. public functions substitute for private activity, ii. economic development causes cultural and welfare expenditures to expand, iii. government intervention may be necessary to manage and finance natural monopolies (AbuBader \& Abu-Qarn, 2003: 571).

Keynesian hypothesis assumes that growing government expenditure enhances economic growth by causing an increase in the level of aggregate demand. High levels of government expenditure may increase employment, profitability and investment via multiplier effects on aggregate demand. According to some economists, expansion of government expenditure related to socio-economic and physical infrastructures contributes positively to economic growth. For instance, government expenditure on health and education stimulates economic growth by increasing the productivity of labour; and government expenditure on infrastructure such as roads, communications, power enhances economic growth by reducing production costs and increasing private sector investment (Nurudeen \& Usman, 2010: 1).

According to Keynesian view, government may reverse economic downturns by borrowing money from the private sector and then returning the money to the private sector through various spending programs. On the other hand, some scholars argue that expansion of government expenditure may slow down the economic performance of developing countries by crowding out private investments, dampening economic stimulus in short run and reducing capital accumulation in the long run (Chude \& Chude, 2013: 6) ${ }^{1}$.

The public expenditure-economic growth relationship has been evaluated from many perspectives in the empirical literature. The reason of the intense interest is related to the matter whether the government should intervene to the economic activity. According to

I For example, government spending may be financed through taxes and/or borrowing. If income taxes increase, this discourages individual from working for long hours or from job search. As a result, income and aggregate demand decreases. If profit tax increases, this increases production costs and causes a decrease in investment. If government increases borrowing, it crowds-out the private investment. Moreover, politicians may increase expenditure and investment in unproductive projects in order to secure that they continue to remain in power. In this way, government impedes growth by causing misallocation of resources (Nurudeen \& Usman, $2010: 1$ 2). 
Classical view, market forces will bring the economy to long-run equilibrium so there is no need for intervention. Besides, Keynesian school of thought supports the use of fiscal policies to augment economic activity in times of recessions. The argument related to the expanding effects of fiscal policies on economic growth has gained additional support with the introduction of new growth theories (Abu-Bader \& Abu-Qarn, 2003: 570).

Barro (1991) investigates the influence of government expenditure on economic growth for 98 countries in the period 1960-1985. The findings of the study indicate an inverse effect of the share of government consumption in GDP on growth rate of real per capita GDP. Furthermore, the study identifies that growth rates are positively related to measures of political stability.

Deverajan et al. (1996) explores the relationship between the composition of government expenditure and economic growth using data from 43 developing countries from 1970 through 1990. The empirical results show that an increase in the share of current expenditure has positive and statistically significant growth effects. By contrast, the impact of the capital component of public expenditure on per-capita growth is negative. This finding indicates that seemingly productive expenditures, could become unproductive if being used in excess.

Bleaney et al. (2001) empirically evaluates the effects of government expenditure on per capita GDP growth by using panel data for 22 OECD countries during 1970-1995 period. The empirical results exhibit strong growth effects of productive government expenditures (e.g., expenditures related to transport and communication, education, health).

Fölster and Henrekson (2001) conduct an econometric panel study in order to detect the growth effects of government expenditure for a sample of rich countries. The sample period covers the years between 1970-1995. The results put forth a robust negative impact of government expenditure on economic growth. It is found that an increase in the expenditure ratio by 10 percentage points causes a decrease in the growth rate on the order of $0.7-0.8$ percentage points.

Dar and AmirKhalkhali (2002) tries to explain differences in economic growth rates of the 19 OECD countries with the role of government size over the 1971-1999 period using a random coefficients model. The empirical results indicate that larger government size dampens economic growth via its adverse impact on factor productivity.

Kar and Taban (2003) evaluates the contribution of disaggregated government expenditures to economic growth both theoretically and empirically. The empirical analyses are performed by utilizing cointegration procedure and by the use of annual data for the 1971-2000 period of Turkish economy. According to the empirical results government expenditures in the form of educational and social expenditures create positive impacts on economic growth while health expenditures affects economic growth negatively. 
Abu-Bader and Abu-Qarn (2003), investigate the causal relationship between government expenditure and economic growth for Egypt (with data for 1975-1998 period), Israel (with data for 1967-1998 period) and Syria (with data 1973-1998 period) by the use of cointegration analysis, impulse response functions and variance decomposition techniques. Causality analyses within a bivariate system, that includes total government spending and economic growth, put forth a bidirectional causality and a negative relationship between government expenditure and economic growth. Causality analyses within a trivariate system, that includes the share of government civilian expenditures in GDP, military burden and economic growth, points a negative effect of military burden and a positive impact of civilian government expenditures on economic growth.

Loizides and Vamvaukas (2005) analyse the causality relationship between the relative size of government and economic growth for Greece, UK and Ireland in both bivariate and trivariate systems, based on cointegration analysis, error correction model and Granger causality tests. The empirical results from bivariate and the trivariate analysis represent that public expenditure Granger causes economic growth in the short run and in the long run for all countries in interest. Furthermore, the results indicate that public spending fosters overall economic development. Besides, it is detected that the causality runs from economic growth to the public expenditure in Greece.

Samudram et al. (2009) investigate the validity of the Keynesian view and the Wagner's Law for Malaysia over 1970-2004 period. The empirical methodology of the study depends on Auto-Regression Distributed Lag (ARDL) model and the bounds test procedure. The estimation results indicate a long run bi-directional causality between GNP and expenditures on administration and health, supporting both Keynesian view and Wagner's Law. For all other government expenditure categories, it is found that the long run causality runs from GNP to the expenditures, supporting Wagner's Law.

Nurudeen and Usman (2010) explore whether government expenditure could be translated to economic growth in Nigeria by using annual data related to 1979-2007 period and by applying cointegration and error correction methods. Their model regresses economic growth on various components of government expenditure. The estimation results of the study represent that total capital expenditure, total recurrent expenditure and government expenditure on education creates negative impacts on economic growth. Besides, it is found that an increase in government expenditure on transport and communication and expenditure on health cause economic growth to increase.

Ighodaro and Oriakhi (2010) evaluate the link between government expenditure and economic growth for Nigeria. The empirical analyses are performed by the use of annual data from 1961 to 2007. The study uses disaggregated data in addition to total government expenditure data. The results obtained from Granger causality tests support the validity of Keynesian hypothesis as pointing a unidirectional causality from government expenditure to economic growth. 
Wu et al. (2010) conduct a panel Granger causality test for the examination of the causal relationship between government expenditure and economic growth. The study utilizes a panel data set that involves 182 countries and cover the period ranging from 1950 to 2004. The empirical results support both Wagner's law and Keynesian view regardless of how the government size and economic growth is measured. This bi-directional causality between government activities and economic growth is also supported when the countries are disaggregated by income levels and the degree of corruption (with the exception of the low-income countries).

Iniguez-Montiel (2010) investigates the relationship between government expenditure and national income for Mexican economy over the period between 1950 and 1999. The study utilizes cointegration analysis, error-correction modelling and Granger causality tests. The empirical findings of the study verify that Wagner's law hold for the case of Mexico.

Magazzino (2012) assesses the empirical relationship between five individual items of public spending (public spending for interests, for final consumption, for labor dependent income, for grants on production, and for public investments) and national income for Italy using time series for the period 1960-2008. Granger causality tests of the study supports Wagner's Law only for passive interests spending in the long-run, and for dependent labor income spending in the short-run. Conversely, findings from the causality test supports Keynesian hypothesis in the case of spending for passive interests, spending for grants on production and spending for public investments in the long-run; and spending for grants on production in the short-run. The study concludes that the relation among public spending and national income is closer to Keynesian view than Wagnerian.

Chude and Chude (2013) represent an empirical evaluation for Nigerian economy. The study investigates the effects of government expenditure in education on economic growth for 1977-2012 period by applying Error Correction Model. The results demonstrate that government expenditure in education creates significantly positive impacts on economic growth of Nigeria in the long run.

Altunç and Aydın (2013) analyse the government expenditure-economic growth nexus for Turkey, Romania and Bulgaria by the use of ARDL bound testing approach and with time series data related to the period 1995-2011. The study explores for the optimal level of public spending for the countries in interest. Optimal government expenditure percentage that maximizes economic growth is estimated to be 25,20 and 22 percent for Turkey, Romania and Bulgaria, respectively. Empirical findings demonstrate that the share of present public expenditure in GDP exceeds optimal public expenditure level for three countries.

Mahmoodi and Mahmoodi (2014) assess the causality relationship between government expenditure and economic growth for the 1970-2010 period of 20 Asian Countries by employing panel causality and panel cointegration techniques. Countries are separated into two panels; one panel involves four advanced economies: Hong Kong, Japan, 
Esener, S.Ç. \& E. İpek (2018), “The Impacts of Public Expenditure, Government Stability and Corruption on Per Capita Growth: An Empirical Investigation on Developing Countries", Sosyoekonomi, Vol. 26(36), 11-32.

South Korea, Taiwan and four newly industrialized countries: China, Malaysia, Philippines, and Thailand. The second panel includes 12 developing countries: Bahrain, Bangladesh, Indonesia, Iran, Iraq, Jordan, Lebanon, Maldives, Oman, Pakistan, Sri Lanka, and Syrian Arab Republic. Empirical findings support bidirectional causality for advanced and newly industrialized countries in the short run and for developing countries in the long run.

Asimakopoulos and Karavias (2016) analyse the influence of government size on economic growth and also inquire the optimal level of government expenditure for a panel of 129 countries for the period 1980-2009. The empirical investigation is utilized by GMM methodology. Empirical results indicate that optimal threshold level of government size is $18.04 \%$ for the full sample. The findings demonstrate that when government size is below that level, an increase in government spending stimulates economic growth; and when the government size is above that level, an increase in government spending retards economic growth. This evidence supports the existence of an inverted u-shaped relationship between economic growth and government spending. Additionally, it is observed that the results from the full sample investigation do not change when the empirical analysis is replicated by dividing the full sample for developed and developing countries.

D’Agostino et al. (2016a) empirically investigate the effects of government spending and corruption on economic growth for a panel of 106 countries over the period 1996-2010 by the use of GMM methodology. Furthermore, the study provides a contribution to the related literature by considering the effects of corruption on the components of government spending such as military spending and investment spending. The empirical findings confirm that government investment spending stimulates economic growth while it is detected that large military burden and high levels of corruption create negative effects on economic growth. Besides, the interactions between corruption-military spending and corruption-investment spending impact economic growth negatively. The results denote that increasing corruption levels enlarges the negative impact of military spending on economic growth. D'Agostino et al. (2016b) put forth a similar empirical analysis for 48 African countries and explore the interaction between different government spending components and corruption; and the influence of this interaction on economic growth performance of the countries in interest. The period examined covers the years between 1996-2010. The results from GMM system indicate that the impact of military spending and corruption on economic growth is negative while the government investment spending enhances economic growth.

\subsection{Government Instability and Economic Growth}

Unstable political environment may reduce investment and the speed of economic development by creating uncertainty. If the propensity of the change of government is high, uncertainty about the new policies of a potential new government increases and raising uncertainty cause economic agents to doubt about taking economic initiatives. On the other hand, foreign investors that pay attention to a stable political environment may opt to invest in countries with less policy uncertainty and less uncertainty about property rights (Alessina et al., 1996: 4). If rulers of the countries are weak and there is a risk of being overthrown, policymakers may allow key groups to engage in rent-seeking activities, which may affect 
economic growth negatively. Even if government changes are peaceful and comply constitutional norms, political instability may affect economic growth through its impact on government myopia. This myopia occurs when forward-looking governments do not pay attention to carry out long-term economic policies due to uncertain re-election prospects (Darby et al., 2004). Theoretically, an inverse relationship from economic performance to political instability is also possible. Poor economic performance of a country may be substantial determinant in social tensions and political instability, which in turn may give rise to the fall of a government (Gurgul \& Lach, 2013: 189).

There are various studies that put forth empirical evidence related to detrimental effects of political instability on economic growth performance of countries. Barro (1991) investigates the impact of political stability on growth by the use of a data set for 98 countries over 1960-1985 period and finds that growth rates are positively related to the measures of political stability. Alessina et al. (1996) determines the relationship between political instability and economic growth in a sample of 113 countries for the period 1950-1982. The results of the empirical analyses indicate a robust negative impact of government in stability on economic growth. Chen and Feng (1996) show that regime instability, political polarization and government repression affects economic growth negatively by employing a cross-sectional analysis of 88 countries over the period of 1974-1990.

Campos and Nugent (2002), investigate the existence and direction of a causal relationship between political instability and economic growth by utilizing Granger causality framework within a data set for 98 developing countries over 1960-1995 period. Two indexes of political instability are constructed. The study reaches no empirical evidence regarding the hypothesized negative and causal relationship between political instability and economic growth. Nevertheless, when the results are broken down by region, a significant negative relationship between political instability and growth is supported for Sub-Saharan Africa sample.

Darby et al. (2004), empirically investigate the link between political instability and economic growth by the use of a political data set to estimate panel regressions for 13 European OECD countries over 1960-1995 period. The results derived from empirical analyses support a strong correlation between increased political instability and the reduction in government investment as a proportion of total fiscal spending.

Jong-A-Pin (2009), firstly derives new measures for political instability by employing an Exploratory Factor Analysis (EFA) on a set of 25 political instability indicators. It is determined that four dimensions of political instability can be distinguished: (1) politically motivated violence, (2) mass political violence, (3) instability within the political regime, and (4) instability of the political regime. Secondly, the study focuses on 5-year averages in a panel of about 90 countries over the period 1974-2003 and examines the causal effect of political instability on economic growth using a dynamic panel system Generalized Method of Moments model. The empirical results demonstrate that the instability of the political regime has a robust and negative impact on economic growth. 
Aisen and Veiga (2013) empirically investigates the effects of political instability on economic growth by using panel data for 169 countries. The sample covers 5 -year periods from 1960 to 2004. The empirical results obtained from the system-GMM estimator for linear dynamic panel data models represent that higher degrees of political instability are associated with lower growth rates of GDP per capita. Furthermore, the results put forth that political instability affects economic growth negatively through its adverse effects on total factor productivity growth and by discouraging physical and human capital accumulation.

Gurgul and Lach (2013) investigates the nexus between political instability and economic growth in $10 \mathrm{CEE}$ countries in transition (Bulgaria, Czech Republic, Estonia, Hungary, Latvia, Lithuania, Poland, Romania, Slovakia, Slovenia) in the period 1990-2009. Political instability is described as a propensity for government change and the results point out a negative impact of political instability on growth.

\subsection{Corruption and Economic Growth}

Treisman (2000) defines corruption as the misuse of public office for private gain. Jain (2001: 73-75) defines three types of corruption: i. grand corruption involving political elite, ii. bureaucratic corruption involving corrupt practices by appointed bureaucrats and iii. legislative corruption involving how legislative votes are impressed by the private interest of the legislator. The corruption results in misallocation of resources and inefficiency in each case (Gyimah-Brempong, 2002: 186).

In theoretical literature, there is no agreement about the effect of corruption on economic growth. According to some authors, corruption may raise economic growth through two mechanisms. First, government employees taking bribes would work harder. Second, corrupt practices like speed money would enable to avoid from bureaucratic delay. In contrast, most of the economists suggest that corruption would lead to lower economic growth and efficient government institutions encourage economic growth. Malfunctioning government institutions are important barriers for investment and innovation (Mauro, 1995: 681-682).

Why corruption retards economic growth can be summarized through five channels: i. corruption distorts incentives and market signals leading to misallocation of resources, ii. corruption lead resources to be channelled into rent seeking activities rather than productive activities, iii. corruption increases the cost of production because it is seen as an inefficient tax on those who are forced to pay it, iv. corruption increases transactions cost because corrupt practices are managed in secrecy and contracts arising from them are legally not enforceable, v. corruption may guide bureaucrats to channel government spending into unproductive sectors that offer opportunities for rent seeking (such as defence) (GyimahBrempong, 2002: 187).

On the other hand, some studies that focus on the impacts of corruption on foreign direct investment, emphasize the "grabbing hand" and "helping hand" of corruption. Grabbing hand view advocates that corruption may adversely affect foreign investment 
inflows and so growth dynamics of the host country by raising uncertainty and by creating remarkable costs for foreign investors. According to helping hand view, corruption creates positive impacts on foreign investment inflows and so economic performance since bribing mechanism eases transactions and accelerates the procedure by greasing the wheels of commerce (Petrou \& Thanos, 2014: 444; Tosun et al., 2014; Quazi, 2014).

Several empirical researches support the link between higher corruption and lower economic growth. Mauro (1995), empirically analyses the impact of corruption on investment and on per capita GDP growth for 58 countries over 1960-1985 period. The corruption variable is defined as the degree to which business transactions involve corruption and questionable payment. The empirical findings from ordinary least squares (OLS) and two stages least squares (2SLS) procedures indicate significantly negative impacts of corruption both on investment and growth variables.

Monte and Papagni (2001) research the long run consequences of corruption on economic growth for Italy. The study applies a dynamic panel data approach based on the data of 20 Italian regions over the 1963-1991 period. The results from empirical analyses demonstrate that corruption has strong negative effects on economic growth.

Mo (2001) investigates the role of corruption in economic growth by using OLS estimations for 46 countries. The sample period covers the years between 1970-1985. The empirical results of the study demonstrate that $1 \%$ increase in the corruption level reduces the growth rate by about $0.72 \%$. Furthermore, the most important channel through which corruption affects economic growth is found to be political instability, which accounts for about $53 \%$ of the total effect.

Gyimah-Brempong (2002) evaluates the effects of corruption on economic growth by using panel data from African countries and a dynamic panel estimator. Empirical analyses are utilized by annual observations for a sample of 21 African countries for the 1993-1999 period. According to the empirical findings, corruption decreases economic growth through reduced productivity of existing resources and decreased investment in physical capital. The results indicate that one-point increase in corruption decreases the growth rates of GDP by between 0.75 and 0.9 percentage points per year and decreases per capita income growth rate by between 0.39 and 0.41 percentage points per year.

Baliamoune-Lutz and Ndikumana (2008) investigate the impact of corruption on economic growth of African countries via public and private investment channels. The study uses unbalanced panel data from 33 African countries for the period 1982-2001. The empirical results represent that corruption affects economic growth through its impact on investment. The impact of corruption on domestic investment is found to be significantly negative. One other important finding of the analyses is the positive effect of corruption on public investment in contrast to its negative effect on private investment. The negative impact on private investment is explained with uncertainty, production and transactions costs caused by corruption. The positive impact on public investment is explained with the 
Esener, S.Ç. \& E. İpek (2018), “The Impacts of Public Expenditure, Government Stability and Corruption on Per Capita Growth: An Empirical Investigation on Developing Countries”, Sosyoekonomi, Vol. 26(36), 11-32.

rent-seeking efforts of corrupt bureaucrats to increase capital expenditure to maximize their private gains.

Me'ndez and Sepu'lveda (2006) analyse the impact of corruption on per capita GDP growth by using data from a large sample of countries during the period 1960-2000. The sample is separated between free and not-free countries. The empirical evidence supports a non-linear relationship between corruption and income growth in the case of free countries. The results imply that economic growth reaches its maximum level for small but positive amounts of corruption. In other words, corruption at low levels may be beneficial for economic growth.

Guetat (2006) evaluates the effect of corruption on growth for MENA (Middle East and North Africa) region over the period 1960-2000. The empirical results indicate that less corruption helps growth due to its positive impact on investment. Furthermore, less corruption stimulates economic growth through increasing profitability of human capital.

Blackburn and Forgues-Puccio (2010) explore the effect of international financial integration on economic development in the existence of corruption. The analysis is based on a dynamic general equilibrium model of a small economy. The results indicate that corruption is always bad for economic development, but its effect is worse if the economy is open than if it is closed. Moreover, it is detected that the incidence of corruption may be affected by both the development and openness of the economy.

Freckleton et al. (2011) links corruption to the impact of FDI on economic growth. The authors emphasize that the possible impact of corruption on FDI inflows may be either positive or negative. In one perspective, foreign investors avoid investing in countries with high levels of corruption. Because they have to bear additional investment costs in the form of bribes to get licences or government permits and those decrease the expected profitability of the investment. Moreover, corruption raises uncertainty since corruption agreements are not enforceable in the courts of law. In the other perspective, corruption may affect FDI inflows positively by improving bureaucratic efficiency. The study applies panel dynamic ordinary least squares methodology for a sample consisting of 42 developing and 28 developed countries and empirically supports that lower levels of corruption boost the impact of FDI on economic growth in the case of developing economies.

Huang (2016) explores the causal relationship between corruption and economic growth for 13 Asia-Pacific Countries (Australia, China, India, Indonesia, Japan, Malaysia, New Zealand, Philippines, Singapore, South Korea, Taiwan, Thailand and Vietnam) by applying bootstrap panel Granger causality methodology. The data set covers for the 19972013 period. The empirical findings indicate a significantly positive causality from corruption to economic growth for South Korea and so supports the "grease the wheels" hypothesis for the country. This evidence puts forth that corruption is not always unfavourable for economic growth. Additionally, the results reveal a significantly positive causality from economic growth to corruption for China. 


\section{Data, Model and Estimation Methodology}

\subsection{Data and Model}

In this study, the relationship between GDP per capita and public policy variables (including government expenditure and stability) will be investigated by using annual panel data for 33 developing countries namely; Albania, Argentina, Armenia, Azerbaijan, Bangladesh, Belarus, Bolivia, Brazil, Bulgaria, Colombia, Dominican Rep., Egypt, El Salvador, Guatemala, Honduras, Indonesia, Jordan, Kazakhstan, Kenya, Malaysia, Mexico, Moldova, Morocco, Panama, Paraguay, Peru, Romania, South Africa, Sri Lanka, Thailand, Tunisia, Turkey and Ukraine. ${ }^{2}$ The sample period covers 1999-2014 time interval. Referred 33 countries are selected through the classifications in IMF and The World Bank. Both IMF's "Emerging \& Developing Economies" and The World Bank's "Lower \& Upper Middle Income" criteria are matched for the determination of these countries. In addition to those classifications, we tried to not to choose countries from small-sized ones or from OPEC (for taking natural resource advantages into account) etc.

Empirical analyses are carried out by using annual datasets from The World Bank's "World Development Indicators" and International Risk Guide's datasets. Dataset is strongly balanced and variables are for 16 years time period for all countries without blank data. The definitions of the variables that are involved into the empirical investigations are reported in Table 1. All variables used in this study are the percentage changes of constant values and/or ratios to GDP and shown below.

Table: 1

Definition of Variables

\begin{tabular}{|l|l|c|}
\hline Name & Definition & Source \\
\hline GDPCAP & Indicates the percentage change in the constant value of Gross Domestic Product Per Capita & WDI 2017 \\
\hline GOVEXP & General Government Final Consumption Expenditure/GDP & WDI 2017 \\
\hline GOVSTAB* & Risk Rating of Government Unity, Legislative Strength and Popular Support & ICRG 2017 \\
\hline CORRUPT* & A Risk Measure of Corruption Within The Political System & ICRG 2017 \\
\hline OPENNESS & The Sum of Exports Plus Imports to Countries' GDP & WDI 2017 \\
\hline POPGR & Population Growth & WDI 2017 \\
\hline
\end{tabular}

* Fiscal risk indicators are calculated and/or consolidated by authors from PRS Group's widely accepted ICRG (International Country Risk Guide) datasets.

\subsection{Estimation Methodology}

The first step of our empirical analysis starts with the linear regression with robust standard errors, which will give us general clues about the relationship between external debt and our independent variables. Secondly, after the "Pooled OLS" estimates we will focus on "Fixed and Random Effects Regressions" which will also be used to understand the linkage between GDP per capita and public policy instruments like expenditure with more reliable results. Lastly -as known-, the developing world data is limited even on the 
websites of international institutions. As our data has no blank pages and it is strongly balanced, it will be wise to observe the variables with four "Dynamic Panel Estimation" methods. Not only for its technical features, it is also a good method for the "small T (time periods)" panel models. By this way, we will try to double check and test the verification of our other three static regressions in more real terms except Hausman test in fixed and random models (Asteriou \& Hall, 2007: 346-349; Esener, 2013: 162-166).

Theoretically, panel data analysis is the estimation of economic relationships by using cross sectional time series data where we have repeated observations, i.e. time series of observations, for each individual rather than havening them on an aggregate level (Greene, 2003: 612; Baltagi, 2013: 1; Arellano, 2003: 1).

The pooled OLS model estimates a basic regression model as presented in Equation (1);

$$
\mathrm{Y}_{i t}=\alpha_{i}+\beta^{\prime} \mathrm{X}_{i t}+\epsilon_{i t}
$$

In this model; $\mathrm{X}_{\mathrm{it}}$ represents the explanatory variables, while t represents the duration and $i$ represents the dimension of the country. This model assumes that all parameters are same for each country (Dunne et al., 2004b: p. 129).

\section{The fixed effects estimator;}

In general assumption of panel data model, it is supposed that the differences among units can be caught in differences in constant term (Greene, 2003). So, the panel data is estimated by the help of dummy variables. For example, when the panel data model is as in second equation below (Brooks, 2008: 490-491);

$$
\begin{aligned}
& y_{i t}=\beta_{1 i t}+\beta_{2 i t} x_{2 i t}+\beta_{3 i t} x_{3 i t}+e_{i t} \\
& \mathrm{i}=1, \ldots ., \mathrm{N} \text { ve } \mathrm{t}=1, \ldots . ., \mathrm{T}
\end{aligned}
$$

It is assumed that " $\beta_{1 i t}=\beta_{1} ; \beta_{2 i t}=\beta_{2} ; \beta_{3 i t}=\beta_{3}$ “. What is seen from this assumption is that only the parameter changes and no time dimension is used in determination of constant term. In other words, this term is constant for all times. As both cross-section and time is considered, the model becomes:

$$
y_{i}=x_{1} \beta_{1 j}+X_{N} \beta_{S}+e
$$


Equation (3) demonstrates that different constants exist for different units. The difference of fixed effects estimator from pooled OLS model is that it allows the intercept to differ across countries.

\section{The random effects estimator;}

Random effects model is more preferred if units are taken randomly or unit is taken from its population as representative. Random effects are outcome of sampling period (Asteriou and Hall, 2007: 344, 345; Wooldridge, 2002: 196-178). $\beta_{1 i}$ in Equation (2) is the random variable and it can be modelled as:

$$
\beta_{1 i}=\overline{\beta_{1}}+\mu_{i}
$$

When Equation (4) is placed in Equation (2);

$$
\begin{aligned}
& Y_{i t}=\left(\overline{\beta_{1}}+\mu_{i}\right)+\beta_{2} x_{2 i t}+\beta_{3} x_{3 i t}+e_{i t} \\
& Y_{i t}=\overline{\beta_{1}}+\sum_{k=2}^{K} \beta_{k} x_{k i t}+\left(e_{i t}+\mu_{i}\right)
\end{aligned}
$$

Equations (5a) and (5b) are reached. The component in (5b) is the general type of error component model. $e_{i t}$ (that represents all errors) and $\mu_{i}$ (that shows specific errors) generate error component term. $\mu_{i}$ shows the differences of the unit and the changes in units according to constant time (Hayashi, 2000: 334, 335; Wooldridge, 2002: 251-289).

There are also other complex solutions available for understanding the relationships between our dependent and independent variables. It is well-known that for a long year data set it is appropriate to use 'static panel' modelling or in other words fixed and random effects estimations. ${ }^{3}$ But with our subject, time and space limitations -because of small T (not longer

3 The selection among fixed effect or random effect model usually depends on the relation between the effects and explanatory variables. If effects are not related to explanatory variables, then random effects estimator is consistent and efficient, whereas fixed effect estimator is also consistent but not efficient. If the effects are related to explanatory variables, fixed effects estimator is consistent and efficient, and random effects estimator is inconsistent (Baltagi et al., 2013). Hausman test is utilized in order to make a selection between fixed effects and random effects. Random effects are chosen over fixed effects if justified by a Hausman test, or if fixed effect estimates are precluded due to the presence of time-invariant variables. 
than 20 years)-, it would be wise using dynamic modelling after static ones (Esener \& İpek, 2015: 622-625; Esener, 2016: 124-126). ${ }^{4}$ Theoretically, dynamic panel can be shown as follows;

$$
Y_{i t}=\alpha Y_{i t-1}+\beta X_{i t}+\phi_{i}+\mathrm{u}_{i t}
$$

This equation includes a lagged dependent variable as an explanatory variable. But still, some econometric problems may arise in these panel data estimations. Those can be listed as follows (Mileva, 2007):

$>$ Endogenous variable may be correlated with the error term due to the probability of causality running between $\mathrm{x}$ and $\mathrm{y}$.

$>$ Time-invariant country characteristics (fixed effects), that are contained in the error term, may be correlated with the explanatory variables.

$>$ The lagged dependent variable, existing in the model as an independent variable, boosts autocorrelation.

$>$ A short time dimension and a larger country dimension of the panel data set create problems in estimations.

In case of observations performed on samples with small numbers of time series, there is an alternative approach to study with the dynamics. This method allows a dynamic specification in differences, with a lagged dependent variable. Adaptation of an instrumental variable method is essential in this approach, since differencing induces a bias in the coefficient on the lagged dependent variable, due to the correlation between it and the unobserved fixed effects in the residual. In order to get unbiased and consistent estimates of the coefficients, Arellano and Bond (1991) generalized the method of moments (GMM) technique that uses lags of the endogenous variables t-2 and is used as instruments earlier (Dunne et al., 2004b: p. 129).

Two different methods can be chosen to make estimations by using GMM. These are so called "difference" and "system". Because of the shortcomings of difference GMM, a new estimator called system GMM is introduced by Arellano and Bover (1995)/Blundell and Bond (1998). The regression in differences and the regression in levels are combined by this estimator. Since Arellano and Bond's (1991) difference GMM estimator has poor finite

4 After examining pooled OLS method, we will use both static and dynamic modelling types of panel data analysis. The main reason behind this opinion is, our data has 'short $T$ ' and relatively 'long $N$ ' which doesn 't fit to macro panels but also has longer time period than micro panels. When a dataset isn't able to cope both problems, it would be wise to use procedures together and create a conclusion for policymakers from the outputs of both analyses (For more information on the subject, please see; Eberhardt, 2011: 7 for the theory and implementation in the empirical works of Dunne et al.; 2004a, 2004b). 
sample properties and is downward biased when $\mathrm{T}$ is relatively small, system GMM is accepted superior in comparison with difference GMM. ${ }^{5}$

\section{Empirical Results}

The aim of the present paper is to investigate the linkages between GDP per capita and public policy variables. As mentioned above, we use "multi" panel data estimation techniques to analyse the effects or nexus between these variables. However, we use this same path with more countries and less time period option. Our proposed modelling framework follows mainly the econometric specification used by the previous literature. The dependent variable version of GDP, GDP growth or GDP per capita have been chosen in the previous studies which are summarized before.

Following most of the prior papers on this subject, we try to augment the bivariate model of GDP per capita and general government final consumption expenditure (as a proxy for the public spending) with other explanatory variables of public policy. Also, we added two main variables of GDP to the equation, namely openness of economy to the world and growth of population for reaching more robust and healthier result (which are most common variables in empirical literature of economic growth). Finally, we estimate three static and four dynamic models which are specified as in the following two equations:

$$
\begin{aligned}
\text { GDPCAP }_{i t}= & \alpha_{0 i}+\alpha_{1 i} \text { GOVEXP }_{i t}+\alpha_{2 i} \text { GOVSTAB }_{i t}+\alpha_{3 i} \text { CORRUPT }_{i t}+\alpha_{4 i} \text { OPENNESS }_{i t} \\
& +\alpha_{5 i} \text { POPGR }_{i t}+\varepsilon_{i t} \\
\text { GDPCAP }_{i t}= & \alpha_{0 i} \text { GDPCAP }_{t-1}+\alpha_{1 i} \text { GOVEXP }_{i t}+\alpha_{2 i} \text { GOVSTAB }_{i t}+\alpha_{3 i} \text { CORRUPT }_{i t} \\
& +\alpha_{4 i} \text { OPENNESS }_{i t}+\alpha_{5 i} \text { POPGR }_{i t}+\varepsilon_{i t}
\end{aligned}
$$

\begin{tabular}{|c|c|c|c|}
\hline & $\begin{array}{l}\text { Pooled OLS } \\
\text { (1) }\end{array}$ & $\begin{array}{c}\text { Fixed Effects (Within) Regression } \\
(\text { (2) }\end{array}$ & $\begin{array}{c}\text { Random Effects GLS Regression } \\
\text { (3) }\end{array}$ \\
\hline & \multicolumn{3}{|c|}{ GDPCAP (Dependent Variable) } \\
\hline GOVEXP & $\begin{array}{r}-.1662324 * * * * \\
(-4.29)\end{array}$ & $\begin{array}{r}-.3186113^{* * * *} \\
(-3.06)\end{array}$ & $\begin{array}{r}-.1839816^{* * * *} \\
(-3.46)\end{array}$ \\
\hline GOVSTAB & $\begin{array}{r}.3906515^{* * * *} \\
(3.81)\end{array}$ & $\begin{array}{r}.2401236 * * \\
(1.99)\end{array}$ & $\begin{array}{r}.3350164^{* * * *} \\
(2.98)\end{array}$ \\
\hline CORRUPT & $\begin{array}{r}-.6832362 * * * * \\
(-2.68)\end{array}$ & $\begin{array}{r}-.6482941 * * \\
(-1.95)\end{array}$ & $\begin{array}{r}-.6445013^{* *} \\
(-2.19)\end{array}$ \\
\hline OPENNESS & $\begin{array}{r}6.420433 * * * \\
(4.08)\end{array}$ & $\begin{array}{r}5.880672 * * * \\
(4.36)\end{array}$ & $\begin{array}{r}6.223486^{* * * * *} \\
(5.42)\end{array}$ \\
\hline POPGR & $\begin{array}{r}-1.233565^{* * * *} \\
(-7.47) \\
\end{array}$ & $\begin{array}{r}-3.21969 * * * \\
(-6.58) \\
\end{array}$ & $\begin{array}{r}-1.443835^{* * * *} \\
(-6.46) \\
\end{array}$ \\
\hline
\end{tabular}

Table: 2

Estimation Results of Static Panel Models 
Esener, S.Ç. \& E. İpek (2018), “The Impacts of Public Expenditure, Government Stability and Corruption on Per Capita Growth: An Empirical Investigation on Developing Countries”, Sosyoekonomi, Vol. 26(36), 11-32.

\begin{tabular}{|c|c|c|c|}
\hline _CONS & $\begin{array}{r}4.192111^{* * * *} \\
(4.24)\end{array}$ & $\begin{array}{r}9.638686^{* * * *} \\
(4.79)\end{array}$ & $\begin{array}{r}5.068299^{* * * *} \\
(3.99)\end{array}$ \\
\hline F (or Wald $\chi^{2}$ ) p Value & 0.0000 & 0.0000 & 0.0000 \\
\hline Hausman Test $\chi^{2} p$ Value & \multicolumn{3}{|c|}{0.0013} \\
\hline N Obs & 528 & 528 & 528 \\
\hline Number of Countries & 33 & 33 & 33 \\
\hline Min Obs & 16 & 16 & 16 \\
\hline
\end{tabular}

Note: ***, **, * indicates statistically significant variables at 1\%, 5\% and 10\% significance level respectively. _CONS represents constant term, $N$ represents number of observations, $F$ represents $F$-test (that tests statistically significance of parameters) and Prob $>F$ values. Figures in the parentheses are $t$ and $z$ statistics. Robust procedure is used in calculating Pooled OLS method.

By examining all these estimations separately with their sub-segments, the pooled OLS estimation (with robust error terms) gives us the clue of a strong statistical relationship between our independent variables and GDP per capita. Moreover, it is seen that the significance levels of all variables are high. This is not exceptional when we examine fixed and random effects models. According to the Hausman test, fixed effects model should be interpreted and it shows that all variables are correlated in some way with our dependent variable. The most powerful connections with GDP per capita are government expenditure, openness and population growth. As we focused through the channels that public policy variables touch GDP, it seems that public consumption expenditure and corruption affects the dependent variable negatively while government stability is at the opposite hand side.

Table: 3

Estimation Results of Dynamic Panel Models

\begin{tabular}{|c|c|c|c|c|}
\hline & $\begin{array}{l}\text { Arellano-Bond One Step } \\
\text { GMM Estimation } \\
\text { (4) }\end{array}$ & $\begin{array}{l}\text { Arellano-Bond Two Step } \\
\text { GMM Estimation } \\
\text { (5) }\end{array}$ & $\begin{array}{c}\text { Arellano-Bover / } \\
\text { Blundell-Bond } \\
\text { Difference GMM } \\
\text { Estimation } \\
(6) \\
\end{array}$ & $\begin{array}{c}\text { Arellano-Bover / } \\
\text { Blundell-Bond } \\
\text { System GMM } \\
\text { Estimation } \\
(7) \\
\end{array}$ \\
\hline & \multicolumn{4}{|c|}{ GDPCAP (Dependent Variable) } \\
\hline $\operatorname{GDPCAP}(-1)$ & $\begin{array}{r}.1556459 * * * \\
(3.20) \\
\end{array}$ & $\begin{array}{r}.1406244 * * * * \\
(7.15) \\
\end{array}$ & $\begin{array}{r}.1609325^{* * * *} \\
(4.21) \\
\end{array}$ & $\begin{array}{r}.173396 * * * \\
(7.03) \\
\end{array}$ \\
\hline GOVEXP & $\begin{array}{r}.8419345 * * * \\
(-4.92) \\
\end{array}$ & $\begin{array}{r}-.7883114 * * * \\
(-24.84) \\
\end{array}$ & $\begin{array}{r}-.81784 * * * \\
(-6.24) \\
\end{array}$ & $\begin{array}{r}-.7885459 * * * \\
(-11.72) \\
\end{array}$ \\
\hline GOVSTAB & $\begin{array}{r}.6670274 * * * \\
(4.16) \\
\end{array}$ & $\begin{array}{r}.5247957 * * * \\
(5.31) \\
\end{array}$ & $\begin{array}{r}.5198794 * * * \\
(3.41) \\
\end{array}$ & $\begin{array}{r}.4780167 * * * * \\
(3.21) \\
\end{array}$ \\
\hline CORRUPT & $\begin{array}{r}-1.05667 * * \\
(-1.94) \\
\end{array}$ & $\begin{array}{r}.66996^{* * * *} \\
(-2.53) \\
\end{array}$ & $\begin{array}{r}-1.102893^{* * *} \\
(-2.09) \\
\end{array}$ & $\begin{array}{r}-1.331413 * * \\
(-2.02) \\
\end{array}$ \\
\hline OPENNESS & $\begin{array}{r}6.582008 * * * \\
(3.59) \\
\end{array}$ & $\begin{array}{r}8.350585 * * * \\
(4.75) \\
\end{array}$ & $\begin{array}{r}7.177043^{* * * *} \\
(4.03) \\
\end{array}$ & $\begin{array}{r}7.944406^{* * * *} \\
(5.52) \\
\end{array}$ \\
\hline POPGR & $\begin{array}{r}-3.362061 * * * \\
(-4.37) \\
\end{array}$ & $\begin{array}{r}-3.653326 * * * * \\
(-6.00) \\
\end{array}$ & $\begin{array}{r}-4.174574 * * * \\
(-7.75) \\
\end{array}$ & $\begin{array}{r}-3.522019 * * * \\
(-7.60) \\
\end{array}$ \\
\hline _CONS & $\begin{array}{r}13.88992 * * * \\
(4.56)\end{array}$ & $\begin{array}{r}14.07147 * * * \\
(12.37) \\
\end{array}$ & $\begin{array}{r}15.58711 * * * * \\
(5.94)\end{array}$ & $\begin{array}{r}15.38832 * * * * \\
(13.35) \\
\end{array}$ \\
\hline Wald $\chi^{2} p$ Value & 0.0000 & 0.0000 & 0.0000 & 0.0000 \\
\hline Sargan/Hansen Test & 266.3312 & 26.78047 & 331.0277 & 28.81994 \\
\hline $\begin{array}{l}2^{\text {nd }} \text { Order } \\
\text { Autocorrelation }\end{array}$ & -2.2626 & -2.244 & -2.3161 & -2.058 \\
\hline N Obs & 462 & 462 & 495 & 495 \\
\hline N Ins & 111 & 111 & 125 & 125 \\
\hline Number of Countries & 33 & 33 & 33 & 33 \\
\hline Min Obs & 14 & 14 & 15 & 15 \\
\hline
\end{tabular}

Note: ***, **, * indicates statistically significant variables at 1\%, 5\% and $10 \%$ significance level respectively. CONS represents constant term, $N$ represents number of observations. Figures in the parentheses are $t$-statistics. Difference/One Step GMM analyses are executed by using Windmeijer (2005) robust methodology and procedure.

As it is mentioned in the theoretical part of this study when time and space has taken into account, we should also investigate the 'dynamic sightseeing' of these variables. In Table 3, it can be seen from the estimates that reliable and robust scores are obtained as it is 
in static ones (because of $\chi^{2}, p$ values and tests that execute autocorrelation and heteroscedasticity). It is possible to interpret from these results that all variables are statistically significant and their signs are all same as the pooled, fixed and random models.

When we deeply examine four dynamic panel estimates together, tests indicate that our model is consistent and the results are similar in all dynamic analyses. First of all, according to the coefficients of variables, all of them have significant effects on GDP per capita. With a strongly (full) balanced panel as ours, the results are as expected with their signs and significancy. As far as we know from the former tested models which are observed and presented above, GDP per capita is mostly influenced by government expenditure, openness and population growth. It is also same here in the dynamic one, too. Except government stability variable seems more powerful in the dynamic effect tests. GOVEXP affect GDPCAP through the same direction with the statistically significant level of $1 \%$. The relative consistent accompaniments of CORRUPT in a negative relationship and GOVSTAB in a positive way are something to attract the attention. The significance levels of all these variables are $95 \%$ or more both in OLS, FE-RE and GMM models. In all regressions tested, the main control variables (which are borrowed from the main literature) namely OPENNESS and POPGR also show strong relationship with GDP per capita. Even the former affects the dependent variable in positive and the latter in negative way.

Table: 4

The Effects of Statistically Significant Variables in All Empirical Analyses (The Direction of Significance for All Estimates)

\begin{tabular}{|c|c|c|c|c|c|c|c|}
\hline GDPCAP & & Esti & & & & ator: & \\
\hline & (1) & (2) & (3) & (4) & (5) & (6) & (7) \\
\hline GOVEXP & & - & & & & & \\
\hline GOVSTAB & & + & & & & & \\
\hline CORRUPT & & - & & & & & \\
\hline OPENNESS & & + & & & & & \\
\hline POPGR & & - & & & & & \\
\hline
\end{tabular}

With the exception of none, variables in all models which tested above are affecting GDP per capita in some way. According to the Table 4, government stability and openness of the economy create positive influence in all models while government consumption expenditure (as a proxy of public spending), corruption and population growth make negative effects. These results indicate that the fiscal and political decision mechanisms should apply carefully by the policymakers and also permanence of those public policies (under the absence of corruption) for a long-time period is essential.

\section{Conclusion}

The aim of the present paper is to investigate the linkages between GDP per capita growth and public policy variables. For this purpose, the study investigates the impacts of public expenditure, government stability and corruption on economic growth with other control variables namely openness and population growth. Our sample includes 33 countries which are classified as "Emerging \& Developing Economies" by IMF and "Lower \& Upper Middle Income" by The World Bank. The empirical analyses are utilized by using strongly balanced annual panel data covering 1999-2014 period. 
We use both static and dynamic regressions to understand the relationship between economic growth and our independent variables. According to the empirical results, we reach a conclusion that government consumption expenditure affects economic growth negatively. From our point of view this is because public spending on consumption hinders allocation of resources in effective means. The impacts of other two main variables that we investigate (namely government stability and corruption) match up with our expectations. They are also relatively coherent with empirical literature of economic growth.

On the basis of our analyses, government stability is affecting the dependent variable positively while the impact of corruption is not. These results point out; all three variables have to be taken into account carefully in developing countries if a government wants to achieve one of its essential targets of shifting its citizens' income through to the higher levels. Hence, policymakers should walk in the safe and stable paths like enhancing democracy, freedom of speech, equality of opportunity etc. Moreover, raising openness of the economy in these countries stimulates economic growth while the growth of population has significant adverse effects on GDP per capita.

\section{References}

Abu-Bader S. \& A.S. Abu-Qarn (2003), “Government Expenditures, Military Spending and Economic Growth: Causality Evidence from Egypt, Israel, and Syria”, Journal of Policy Modeling, (25), 567-583.

Aisen, A. \& F.J. Veiga (2013), "How Does Political Instability Affect Economic Growth?”, IMF Working Paper, WP/11/12, 1-29.

Alesina, A. \& S. Ozler \& N. Roubini \& P. Swagel (1996), "Political Instability and Economic Growth", NBER Working Paper Series, Working Paper No. 4173, 1-49.

Altunc, O.F. \& C. Aydın (2013), "The Relationship between Optimal Size of Government and Economic Growth: Empirical Evidence from Turkey, Romania and Bulgaria", Procedia Social and Behavioral Sciences, (92), 66-75.

Arellano, M. (2003), Panel Data Econometrics, Oxford University Press, New York.

Arellano, M. \& S. Bond (1991), "Some Tests of Specification for Panel Data: Monte Carlo Evidence and an Application to Employment Equations", Review of Economic Studies, (58), 277297.

Arellano, M. \& O. Bover (1995), "Another Look at the Instrumental Variable Estimation of ErrorComponents Models", Journal of Econometrics, (68), 29-51.

Asimakopoulos, S. \& Y. Karavias (2016), "The Impact of Government Size on Economic Growth: A Threshold Analysis", Economic Letters, (139), 65-68.

Asteriou, D. \& S.G. Hall (2007), Applied Econometrics: A Modern Approach Using Eviews and Microfit, Revised Ed., Palgrave Macmillan, New York.

Baliamoune-Lutz, M. \& L. Ndikumana (2008), "Corruption and Growth: Exploring the Investment Channel”, University of Massachusetts Economics Department Working Paper Series, 121.

Baltagi, B.H. (2013), Econometric Analysis of Panel Data, Fifth Edition, John Wiley \& Sons, Ltd., Chichester. 
Barro, R.J. (1991), "Economic Growth in a Cross Section of Countries”, The Quarterly Journal of Economics, 106(2), 407-443.

Blackburn, K. \& G.F. Forgues-Puccio (2010), "Financial Liberalization, Bureaucratic Corruption and Economic Development", Journal of International Money and Finance, (29), 1321-1339.

Bleaney, M. \& N. Gemmell \& R. Kneller (2001), "Testing the Endogenous Growth Model: Public Expenditure, Taxation and Growth Over the Long Run", Canadian Journal of Economics, 34(1), 36-57.

Blundell, R. \& S. Bond (1998), "Initial Conditions and Moment Restrictions in Dynamic Panel Data Models", Journal of Econometrics, 87, 115-143.

Brooks, C. (2008), Introductory Econometrics for Finance, Cambridge University Press, Cambridge.

Campos, N.F. \& J.B. Nugent (2002), "Who is Afraid of Political Instability?”, Journal of Development Economics, (67), 157-172.

Chen, B. \& Y. Feng (1996), "Some Political Determinants of Economic Growth: Theory and Empirical Implications”, European Journal of Political Economy, (12), 609-627.

Chude, N.P. \& D.I. Chude (2013), "Impact of Government Expenditure on Economic Growth in Nigeria”, International Journal of Business and Management Review, 1(4), 64-71.

D’agostino, G. \& J.P. Dunne \& L. Pieroni (2016a), “Government Spending, Corruption and Economic Growth", World Development, (84), 190-205.

D'agostino, G. \& J.P. Dunne \& L. Pieroni (2016b), "Corruption and Growth in Africa”, European Journal of Political Economy, (43), 71-88.

Dar, A.A. \& S. AmirKhalkhali (2002), "Government Size, Factor Accumulation and Economic Growth: Evidence from OECD Countries”, Journal of Policy Modeling, (24), 679-692.

Darby, J. \& C. Li \& V.A. Muscatelli (2004), "Political Uncertainty, Public Expenditure and Growth", European Journal of Political Economy, (20), 153-179.

Devarajan, S. \& V. Swaroop \& H. Zou (1996), "The Composition of Public Expenditure and Economic Growth", Journal of Monetary Economics, (37), 313-344.

Dunne, J.P. \& S. Perlo-Freeman \& A. Soydan (2004a), "Military Expenditure and Debt in South America", Defence and Peace Economics, 15(2), 173-187.

Dunne, J.P. \& S. Perlo-Freeman \& A. Soydan (2004b), "Military Expenditure and Debt in Small Industrialised Economies: A Panel Analysis", Defence and Peace Economics, 15(2), 125-132.

Eberhardt, M. (2011), Panel Time-Series Modeling: New Tools for Analyzing XT Data, <http://www.stata.com/meeting/uk11/abstracts/UK11_eberhardt.pdf>, 21.06.2017.

Esener, S.Ç. (2013), Gelişmekte Olan Ülkelerde ve Türkiye'de Dış Borçlanmanın Belirleyicilerinin Incelenmesi: 1980-2010, T.C. Maliye Bakanlığ1, Strateji Geliştirme Başkanlığ Y Yayınları, Hermes Matbaacilık, Ankara Yayın No: 2013/424.

Esener, S.Ç. (2016), “Türkiye de Aileden Biri Olsaydı: Maliye Politikasının Seçilmiş Avrupa Birliği Üyesi Ülkelerde ve Türkiye'de Ekonomik Büyüme Üzerindeki Etkileri”, Journal of Life Economics, 3(3), 119-138.

Esener, S.Ç. \& E. İpek (2015), "Expanding Effects of Military Expenditures on External Debt in Developing Countries", Journal of Business, Economics \& Finance, 4, 617-632.

Fölster, S. \& M. Henrekson (2001), “Growth Effects of Government Expenditure and Taxation in Rich Countries", European Economic Review, (45), 1501-1520. 
Esener, S.Ç. \& E. İpek (2018), “The Impacts of Public Expenditure, Government Stability and Corruption on Per Capita Growth: An Empirical Investigation on Developing Countries”, Sosyoekonomi, Vol. 26(36), 11-32.

Freckleton, M. \& A. Wright \& R. Craigwell (2012), "Economic Growth, Foreign Direct Investment and Corruption in Developed and Developing Countries", Journal of Economic Studies, 39(6), 639-652.

Gurgul, H. \& Q. Lach (2013), "Political Instability and Economic Growth: Evidence from Two Decades of Transition in CEE", Communist and Post-Communist Studies, (46), 189-202.

Guetat, I. (2006), "The Effects of Corruption on Growth Performance on the Mena Countries", Journal of Economics and Finance, 30(2), 208-221.

Gyimah-Brempong, K. (2002), "Corruption, Economic Growth and Income Inequality in Africa”, Economics of Governance, (3), 183-209.

Greene, W.H. (2003), Econometric Analysis, 5th Edition, Prentice Hall, London.

Hayashi, F. (2000), Econometrics, Princeton University Press, New Jersey.

Huang, C. (2016), "Is Corruption Bad for Economic Growth? Evidence from Asia-Pacific Countries", North American Journal of Economics and Finance, (35), 247-256.

Ighodaro, C.A.U. \& D.E. Oriakhi (2010), "Does the Relationship between Government Expenditure and Economic Growth Follow Wagner's Law in Nigeria?", Annals of the University of Petroşani, Economics, 10(2), 185-198.

International Country Risk Guide (ICRG), The PRS Group Database, $<$ http://epub.prsgroup.com/the-countrydata-gateway>, 26.06.2017.

Jain, A.K. (2001), “Corruption: A Review”, Journal of Economic Surveys, 15(1), 71-121.

Jong-A-Pin, R. (2009), "On the Measurement of Political Instability and Its Impact on Economic Growth", European Journal of Political Economy, (25), 15-29.

Kar, M. \& S. Taban (2003), "The Impacts of the Disaggregated Public Expenditure on Economic Growth", Ankara Üniversitesi SBF Dergisi, 58(3), 145-169.

Loizides, J. \& G. Vamvoukas (2005), “Government Expenditure and Economic Growth: Evidence from Trivariate Causality Testing", Journal of Applied Economics, 8(1), 125-152.

Magazzino, C. (2012), "Wagner Versus Keynes: Public Spending and National Income in Italy", Journal of Policy Modeling, (34), 890-905.

Mahmoodi, M. \& E. Mahmoodi (2014), "Government Expenditure-GDP Nexus: Panel Causality Evidence”, International Journal of Economy, Management and Social Sciences, 3(1), $37-42$.

Mauro, P. (1995), "Corruption and Growth", The Quarterly Journal of Economics, 110(3), 681-712.

Me'ndez, F. \& F. Sepu'lveda (2006), "Corruption, Growth and Political Regimes: Cross Country Evidence”, European Journal of Political Economy, (22), 82- 98.

Mileva, E. (2007), Using Arellano-Bond Dynamic Panel GMM Estimators in Stata: Tutorial with Examples Using Stata 9.0, Economics Dept., Fordham University.

Mo, P.H. (2001), “Corruption and Economic Growth”, Journal of Comparative Economics, (29), 6679.

Monte, A.D. \& E. Papagni (2001), "Public Expenditure, Corruption, and Economic Growth: The Case of Italy", European Journal of Political Economy, 17, 1-16.

Nurudeen, A. \& A. Usman (2010), "Government Expenditure and Economic Growth in Nigeria, 1970-2008: A Disaggregated Analysis", Business and Economics Journal, Vol. 2010: BEJ-4, 1-11. 
Ono, H. (2014), “The Government Expenditure-Economic Growth Relation in Japan: An Analysis by Using the ADL Test for Threshold Cointegration", Applied Economics, 46(28), 35233531.

Petrou, A.P. \& I.C. Thanos (2014), "The Grabbing Hand or The Helping Hand View of Corruption: Evidence from Bank Foreign Market Entries", Journal of World Business, (49), 444-454.

Quazi, R.M. (2014), "Corruption and Foreign Direct Investment in East Asia and South Asia: An Econometric Study", International Journal of Economics and Financial Issues, 4(2), 231-242.

Samudram, M. \& M. Nair \& S. Vaithilingam (2009), "Keynes and Wagner on Government Expenditures and Economic Development: The Case of a Developing Economy", Empirical Economics, (36), 697-712.

Tosun, M.U. \& M.O. Yurdakul \& P. Varol-İyidoğan (2014), “The Relationship between Corruption and Foreign Direct Investment Flows in Turkey: An Empirical Examination", Transylvanian Review and Administrative Sciences, (42), 247-257.

Treisman, D. (2000), "The Causes of Corruption: A Cross-National Study", Journal of Public Economics, (76), 399-457.

Windmeijer, F. (2005), “A Finite Sample Correction for the Variance of Linear Efficient Two-Step GMM Estimators", Journal of Econometrics, (126), 25-51.

Wooldridge, J.M. (2002), Econometric Analysis of Cross Section and Panel Data, The MIT Press, Massachusetts.

World Bank, World Bank Database, <http://data.worldbank.org>, 26.06.2017.

Wu, S. \& J. Tang \& E.S. Lin (2010), “The Impact of Government Expenditure on Economic Growth: How Sensitive to the Level of Development?", Journal of Policy Modeling, (32), 804817.

Annex: 1

List of Developing Countries Used in Panel Data Analysis

\begin{tabular}{|c|c|c|}
\hline Albania & Egypt & Morocco \\
Argentina & Pl Salvador & Paraguay \\
Armenia & Guatemala & Peru \\
Azerbaijan & Honduras & Romania \\
Bangladesh & Indonesia & South Africa \\
Belarus & Jordan & Sri Lanka \\
Bolivia & Kazakhstan & Thailand \\
Brazil & Kenya & Tunisia \\
Bulgaria & Malaysia & Turkey \\
Colombia & Mexico & Ukraine \\
\hline
\end{tabular}

